\title{
Skin Damage and Aesthetic Disadvantage Observed in Women in the Hand Craft Shelling Chain of Cashew Nuts in a Factory to Bobo-Dioulasso, Burkina Faso
}

\author{
Jean-Baptiste Andonaba ${ }^{*}$, Sandrine Sanou Lompo ${ }^{2}$, Vincent Ouédraogo ${ }^{2}$, Flore Ouédraogo², \\ Muriel S. Ouédraogo², Issouf Konaté1, Boukary Diallo' , Adama Traoré ${ }^{2}$
}

${ }^{1}$ INSSA, Université Nazi Boni de Bobo-Dioulasso, Bobo-Dioulasso, Burkina Faso

${ }^{2}$ UFR/SDS, Université Joseph Ki-Zerbo de Ouagadougou, Ouagadougou, Burkina Faso

Email: `jb_andonaba@yahoo.fr, sandrine_2sanon@yahoo.fr, oued_vince@hotmail.com,flodelwen@yahoo.fr,

kletio@yahoo.fr,bkrdiallo@yahoo.fr,adma_traore@hotmail.com

How to cite this paper: Andonaba, J.-B., Lompo, S.S., Ouédraogo, V., Ouédraogo, F., Ouédraogo, M.S., Konaté, I., Diallo, B. and Traoré, A. (2017) Skin Damage and Aesthetic Disadvantage Observed in Women in the Hand Craft Shelling Chain of Cashew Nuts in a Factory to Bobo-Dioulasso, Burkina Faso. Journal of Cosmetics, Dermatological Sciences and Applications, 7, 211-220.

https://doi.org/10.4236/jcdsa.2017.73020

Received: August 2, 2017

Accepted: September 11, 2017

Published: September 14, 2017

Copyright $\odot 2017$ by authors and Scientific Research Publishing Inc. This work is licensed under the Creative Commons Attribution International License (CC BY 4.0).

http://creativecommons.org/licenses/by/4.0/

\begin{abstract}
Introduction: Occupational dermatitis has long been an unforeseen consequence of industrial progress. Today, most occupational diseases are dermatosis throughout the world. The morbidity and the various prejudices concern different actors, especially those of the cashew industry in Bobo-Dioulasso to Burkina Faso. We considered it appropriate to conduct this study in women who handle cashew nuts in the cashew nut shelling station at a factory. The aim is to contribute to the search for preventive and curative solutions adapted to this health risk. Methods: This was a prospective cross-sectional study with a descriptive purpose in May 2016. The study involved 112 women present in the factory in the shelling unit and having given their approval during our visit. This station is occupied by 118 women. Results: The prevalence of all dermatosis and dermatitis was estimated respectively at $98.21 \%$ and $88.39 \%$. The manual shelling station with a shearing machine was exclusively occupied by illiterate women $(72.3 \%)$ without personal protective equipment, with an average age of $33.74 \pm 8.49$ years. Among the clinical forms of contact dermatitis, the erythematous contact dermatitis was most observed (86.4\%), followed by palmar keratoderma (70.9\%), nail disorders (33.6\%) and chemical burns (30\%). The implication of Cashew Nut Shell Liquid (CNSL) was established with identified promoting factors. Aesthetic damage related to hand injuries had a significant psychosocial impact in 97.32\% of cases. Discussion: Few studies exist on dermatitis and the health impacts in the reality of cashew because they reach vulnerable subjects without social welfare and health protection. The cashew nuts shell contains a
\end{abstract}


highly irritating brown oily liquid. Dermatitis occurs during contact with this oily juice. The international literature reports this corrosive effect throughout the history of the chain. Human factors, technical factors and work environment aggravate the situation and compromize workwomen health. Conclusion: Cashew huskers had dermatitis with an impact on daily life. Working conditions and security of employment, hygiene attitudes and anacardic acid were identified as causes of this situation. It is imperious to take measures in collaboration with the occupational physicians to ensure these women's health at work and improve their quality of life.

\section{Keywords}

Dermatitis, Aesthetic, Shelling Unit, Cashew, Anacardic Acid, Burkina Faso

\section{Introduction}

Occupational diseases result from dysfunctions arising from the interactions between human factors, technical factors, work environment and factors related to work organization [1]. Today, about $20 \%$ - 34\% of occupational diseases in Europe are dermatosis [2]. Occupational dermatosis accounts for more than $10 \%$ of the cutaneous pathology in France and affects $1 \%$ to $2 \%$ of active employees [3]. In Burkina Faso, according to the 2009 report of the National Social Security Fund (CNSS) conducted by Ouedraogo et al. on the medico-legal aspects of occupational dermatosis, into the 41 occupational diseases reported to the CNSS from 1979 to 2009 , four were occupational dermatitis, with a frequency of $9.8 \%[4]$.

Processing units of cashew nuts in their diversity nowadays face enormous difficulties in managing health risks. The shell of the nut is composed of two shells, one on the outside green and fine, the other internal brown and hard, separated by a cavity structure which contains a caustic phenolic resin consisting of $90 \%$ acid and 10\% cashew Cardol called cashew balm. The contents of the husk defined as "CNSL" or Cashew Nut Shell Liquid (corrosive oil contained in the shell of the nut) or cashew acid or anacardic acid, cause damages on the integument. [5]

The cashew factory located in Bobo-Dioulasso employs more than 250 of whom $90 \%$ are female. The factory shelling station employs 118 women. It has capacity for processing 1.300 tons of raw cashew nuts per year. The finished products are transported to supermarkets in Europe and marketed in BIO and Fair-trade. Throughout the process of transformation, the cashew kernel is largely processed by hand to remove the finished product [5]. It result from irritated and allergic dermatitis related to mechanical and chemical factors; there are main factors, and sometimes associated [6].

Few studies exist in Africa and around the world on the health impacts in the reality of cashew nuts. The shelling station in Bobo-Dioulasso is exclusively oc- 
cupied by vulnerable women. We conducted a study in a cashew processing factory to study the impact of cashew nut manipulation on the health of workwomen. The aim was to contribute to the search for a preventive and curative solution adapted to this health risk which gradually compromises the hope of these courageous women, in search of their financial autonomy.

\section{Methods}

We conducted a prospective cross-sectional study with descriptive purpose in May 2016 in a cashew processing factory. The sampling took into account all the women at the shelling station and present during the passage of the investigation team consisting of a dermatologist, an occupational doctor, three interned trainees in Medicine, a preparer in Pharmacy and a photographer. It was a survey to single passage during a day in a workstation at risk according to the reports of the factory. The variables studied were socio-demographic, clinical and concerned working conditions. A standardized survey form was designed for data collection. She was informed by a direct face-to-face interview with the woman completed by the physical examination data. The data entered on the computer using the Epi Data and Word software, were analyzed using the Epi Info version 7 software. The Pearson Chi square test was used to compare the proportions with a significance level of 0.05 . The stata 12 software was also used to analyze the correlations of variables at the $25 \%$ threshold. Ethically, when a dermatosis was found in a woman, advice was given and a masterful preparation (White Vaseline + almond oil + weak corticosteroid) was given as well as an adapted medical prescription according to the cases. The feedback on the validated recommendations was given to the company and the workers.

\section{Results}

During our study, 112 female huskers were included, questioned, examined and among them, 110 had at least one dermatosis and 99 had dermatitis, with respective prevalences of $98.21 \%(110 / 112)$ and $88.39 \%$ (99/112). In terms of socio-demographic characteristics, the cashew shelling station was exclusively occupied by women. The mean age in our study population was $33.74 \pm 8.49$ years with extremes of 18 and 65 years and a median of 34 years. The age group of 30 to 39 years was the most represented with $38.39 \%$. In terms of education, non-literate workers accounted for $72.3 \%$ of our population. Of the $112 \mathrm{em}$ ployees, 109 lived in a couple (97.3\%). At the interrogation, the notion of personal atopy was found in 10 employees $(8.9 \%)$. The notion of family atopy was found in 6 employees (5.4\%). Of the 112 employees, 74 had previously had a dermatological history related to cashew nuts. The mode of occurrence was specified in 64 employees: the occurrence was regular in 46 cases i.e. $71.87 \%$ and occasional in 18 i.e. $28.13 \%$. The occurrence of dermatitis resulted in a work stoppage in 14 employees, i.e. $12.5 \%$ (14/112). This stop lasted on average 6.29 days \pm 4.68 days with extremes of 2 and 14 days. The cessation of work resulted 
in the modification of the signs of dermatitis in 12 cases without treatment. The average length of service in the unit was $2.78 \pm 1.75$ years with extremes of 1 day to 7 years. The median was 3 years. All the workwomen in our sample worked full-time. The majority of them did not use protective equipment, ie 109 out of 112 employees (97.32\%). The cashew kernel is largely processed by hand to remove the finished product.

During labor all women used pure cashew oil in 100\% (112/112), castor oil $11.6 \%(13 / 112)$, and cotton oil 9\% (10/112) to relieve the corrosive effects of the nut content on the skin. The soap was systematically used by 105 out of 112 women for cleaning just after work (93.75\%). To clean dead skin and stains, rubbing stone and lemon were used respectively by $64(57.1 \%)$ and 32 patients (28.6\%). Of the 105 employees using the soap, the brand name was specified by 86 employees (81.9\%). Traditional black soap and the SN CITEC factory soap were the most used, with respective proportions of $39.0 \%$ (41/105) and $25.7 \%$ (27/105). Some rare and curious products were used by 19 (18.1\%) women at home to eradicate skin damage: the tamarind juice per 5 women, the brewery residues (BRAKINA BREWERY) by 5 , the ash by 3 and the bleach by 3 women.

The analysis of the elementary lesions made it possible to pose 110 diagnosis of contact dermatitis (88.39\%) with many clinical presentations: inflammatory erythematous lesions (Figure 1) (86.4\%), palmar keratoderma (Figure 2) (70.9\%), skin detachment by chemical burns due to CNSL (Figure 3) (30.0\%). Table 1 shows the frequency of its clinical presentations. On the topographic level, lesions were mainly on the palms of the hands in $93.75 \%$, the back of the hands in $91.07 \%$, the nails $30.36 \%$, the forearms in $24.11 \%$ and the ocular conjunctiva in $2.7 \%$. The dermatitis evolved from an average of 2.35 years with extremes of 1 day to 6 years. The median was 3 years. Pruritus and lichenification were the main associated signs, with frequencies of $49.1 \%$ and $40.0 \%$ respectively. Contact with cashew is the main etiological factor in 104 cases, i.e. $94.55 \%$ of those who presented lesions and who worked without protection.

At the multivariate statistical analysis, erythematous contact dermatitis (ECD) were significantly associated with a medical past history of dermatitis $(\mathrm{p}=0$, 0005) (Table 2). Palmar keratoderma were significantly associated with those
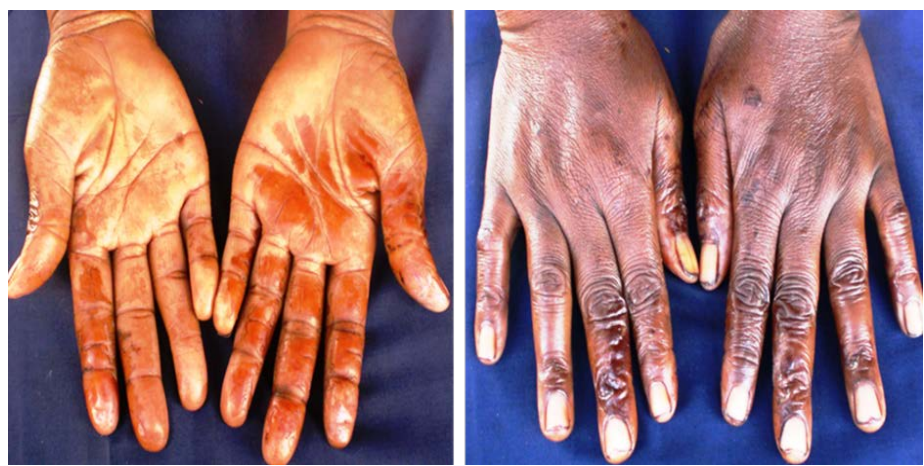

Figure 1. Erythematous contact dermatitis was the clinical form most observed. 

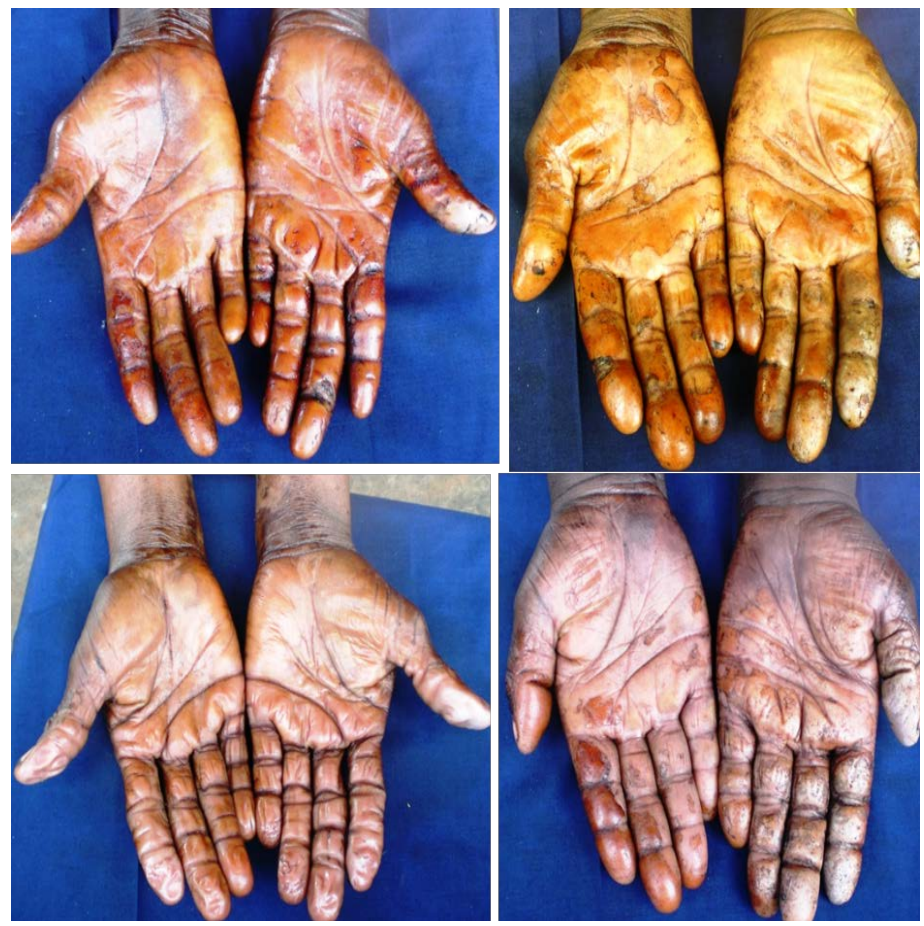

Figure 2. Palmar keratoderma by prolonged and repeated contact with Cashew Nut Shell Liquid (CNSL).
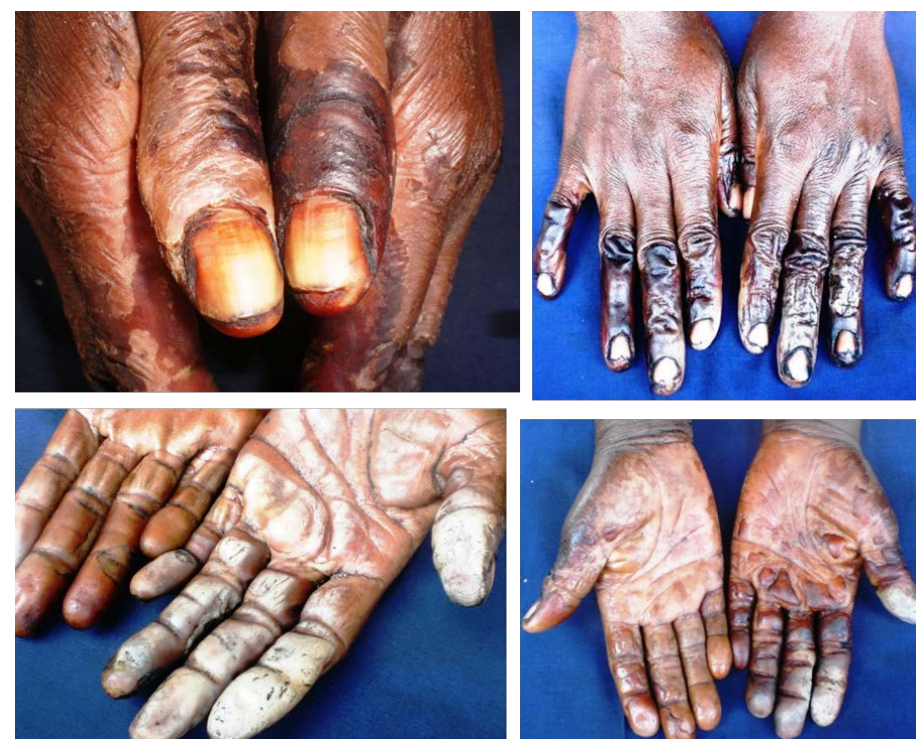

Figure 3. Burning skin and detachments from contacts with Cashew Nut Shell Liquid (CNSL).

who use castor oil $(\mathrm{P}=0.0020)$ and oil from cotton $(\mathrm{p}=0.0081)$ (Table 3$)$. The use of black soap ( $p=0.0303)$ and an age of more than 4 years $(p=0.0044)$ were associated with skin detachment; this is recorded in the following table (Table 4). The hands lesions had a psychological impact on 109 workwomen (97.32\%). The following table shows the distribution of patients according to the type of psychosocial repercussion (Table 5). 
Table 1. Distribution of patients according to the anatomo-clinical form of dermatitis among the 110 cases of dermatosis.

\begin{tabular}{ccc}
\hline Fault finding procedure & Staff & Percentage (\%) \\
\hline ECD $^{*}$ & 95 & 86.4 \\
Palmar keratoderma & 78 & 70.9 \\
Skin detachment & 33 & 30.0 \\
Onyxis & 24 & 21.8 \\
Paronychia & 13 & 11.8 \\
Other Diagnosis & 4 & 3.6 \\
\hline
\end{tabular}

ECD $^{*}$ : Erythematous Contact Dermatitis; Other ${ }^{*}$ Allergic Contact Dermatitis, Injuries by device and Scar of injuries.

Table 2. Distribution of Erythematous Contact Dermatitis (ECD) according the sociodemographic characteristics.

\begin{tabular}{|c|c|c|c|c|c|}
\hline \multirow[b]{2}{*}{ The variables } & \multicolumn{3}{|c|}{ Full model } & \multicolumn{2}{|l|}{ Final model } \\
\hline & DCI $n(\%)$ & $\begin{array}{l}\text { Adjusted OR } \\
\text { [Ci95\%] }\end{array}$ & $\mathrm{P}$-value & $\begin{array}{l}\text { Adjusted OR } \\
\text { [Ci95\%] }\end{array}$ & $\mathrm{P}$-value \\
\hline \multicolumn{6}{|l|}{ Average Age (years) } \\
\hline$<33.7$ & $51(53.6)$ & $6.16[1.66-22.79]$ & 0.0066 & $1.51[0.38-5.88]$ & 0.5549 \\
\hline$\geq 33.7$ & $44(46.4)$ & 1 & & 1 & \\
\hline \multicolumn{6}{|c|}{ School enrolment level } \\
\hline No & $76(80)$ & $4[0.49-32.01]$ & 0.1914 & $1.15[0.09-14.05]$ & 0.9075 \\
\hline School & $19(20)$ & 1 & & 1 & \\
\hline \multicolumn{6}{|l|}{ Seniority } \\
\hline $1-2$ years & $27(28.5)$ & $1.11[0.18-6.55]$ & 0.9074 & & \\
\hline $2-3$ years & $12(12.6)$ & 1 & & & \\
\hline 3 - 4years & $21(22.1)$ & $0.8[0.19-0.04]$ & 0.7181 & & \\
\hline$>4$ years & $35(36.8)$ & $1.29[0.34-4.93]$ & 0.7037 & & \\
\hline \multicolumn{6}{|l|}{ Oil use } \\
\hline Shea butter & $10(10.5)$ & 1 & & & \\
\hline Cotton & $10(10.5)$ & $0.53[0.12-2.22]$ & 0.3876 & & \\
\hline Ricin & $75(78.9)$ & $0.8[0.15-4.1]$ & 0.7892 & & \\
\hline \multicolumn{6}{|l|}{ Soap for cleaning } \\
\hline Without soap & $27(28.4)$ & $3.9[0.41-36.23]$ & 0.2314 & $6.45[0.55-75.32]$ & 0.1367 \\
\hline Kabakourou & $12(12.6)$ & 1 & & 1 & \\
\hline SN Citec & $21(22.1)$ & $1.23[0.37-4.08]$ & 0.7268 & $1.47[0.35-6.25]$ & 0.6023 \\
\hline Black soap & $35(36.9)$ & $4.4[0.79-23.7]$ & 0.0898 & $5.11 \mid 0.7-37.34]$ & 0.1077 \\
\hline \multicolumn{6}{|l|}{ Background } \\
\hline Without history & $22(23.2)$ & $2.66[0.49-14.24]$ & 0.2535 & $2.67[0.41-17.79]$ & 0.3049 \\
\hline Allergy & $9(9.5)$ & 1 & & 1 & \\
\hline Dermatological & $64(67.3)$ & $18.9[3.95-90.47]$ & 0.0002 & $19.62[3.68-104.4]$ & 0.0005 \\
\hline
\end{tabular}

\section{Discussion}

Our study was transversal prospective in a professional environment. The main limit of our study was the bias of information concerning socio-demographic data and working conditions. 
Table 3. Distribution of palmar keratoderma according to the sociodemographic characteristics.

\begin{tabular}{|c|c|c|c|c|c|}
\hline \multirow[b]{2}{*}{ The variables } & \multicolumn{3}{|c|}{ Full model } & \multicolumn{2}{|c|}{ Final model } \\
\hline & $\begin{array}{c}\text { Palmar } \\
\text { Keratoderma } \\
(\%)\end{array}$ & $\begin{array}{l}\text { Adjusted OR } \\
\text { [Ci95\%] }\end{array}$ & $\mathrm{P}$-value & $\begin{array}{l}\text { Adjusted OR } \\
\text { [Ci95\%] }\end{array}$ & P-value \\
\hline \multicolumn{6}{|l|}{ Average Age (years) } \\
\hline$<33.7$ & $33(47.8)$ & 1 & 0.4645 & & \\
\hline$\geq 33.7$ & $36(52.2)$ & $1.32[0.62-2.85]$ & & & \\
\hline \multicolumn{6}{|c|}{ School enrolment level } \\
\hline No & $57(82.6)$ & $0.92[0.34-2.47]$ & 0.8705 & & \\
\hline School & $12(17.4)$ & 1 & & & \\
\hline \multicolumn{6}{|l|}{ Seniority } \\
\hline 1 - 2 years & $21(30.4)$ & $0.94[0.25-3.5]$ & 0.9301 & & \\
\hline $2-3$ years & $9(13.0)$ & 1 & & & \\
\hline 3 - 4years & $17(24.6)$ & $0.98[0.33-2.93]$ & 0.9847 & & \\
\hline$>4$ years & $22(32.0)$ & $0.64[0.24-1.67]$ & 0.3622 & & \\
\hline \multicolumn{6}{|l|}{ Oil use } \\
\hline Shea butter & $3(4.3)$ & 1 & & & \\
\hline Cotton & $3(4.3)$ & $0.12[0.03-0.51]$ & 0.0036 & $0.14[0.03-0.60]$ & 0.0081 \\
\hline castor & $63(91.4)$ & $0.11[0.02-0.45]$ & 0.002 & $0.10[0.02-0.44]$ & 0.0020 \\
\hline \multicolumn{6}{|l|}{ Soap for cleaning } \\
\hline Without soap & $15(21.7)$ & $1.3[0.34-5.05]$ & 0.6851 & & \\
\hline Kabakourou & $9(13.04)$ & 1 & & & \\
\hline SN Citec & $25(36.2)$ & $1.14[0.42-3.11]$ & 0.7895 & & \\
\hline Black soap & $20(29.06)$ & $1.33[0.45-3.8]$ & 0.5966 & & \\
\hline \multicolumn{6}{|l|}{ Background } \\
\hline Without history & $20(28.9)$ & $0.42[0.1-1.74]$ & 0.2352 & $0.81[0.16-3.96]$ & 0.7953 \\
\hline Allergy & $4(5.8)$ & 1 & & & \\
\hline Dermatological & $45(65.3)$ & $1.6[0.68-3.74]$ & 0.2719 & $1.86[0.74-4.68]$ & 0.1851 \\
\hline
\end{tabular}

During our study at the shelling station, the prevalence of dermatitis was 88.39\%. These results are significantly higher than those of Cissé and al. [7] in Guinea who found $41.72 \%$ of contact dermatitis at this post. The increase in cases is due to the industrial and semi-industrial transformation which is growing strongly in Burkina Faso. This recent development supported by the Non-governmental organization (ONG Oxfam), now seems to attract a lot of investors [4]. All employees were women living in precarious situations. In this female population, $72.3 \%$ were uneducated. Few articles exist on dermatitis and the health impacts in the reality of cashew nets because they reach subjects at the bottom of the scale without social and health protection. It is a subsistence job for vulnerable women [5] [7].

Regarding working conditions, the women worked without a protective device with a shearing machine. To calm the pain and repair after-effects caused by anacardic acid the women used pure cashew oil in which they regularly plunge their hands with immediate relief according to them. In our study each woman used other products at home after work. What is worrying is that these products 
Table 4. Distribution of skin detachments (chemical burns) according to the socio-demographic characteristics.

\begin{tabular}{|c|c|c|c|c|c|}
\hline \multirow[b]{2}{*}{ The variables } & \multicolumn{3}{|c|}{ Full model } & \multicolumn{2}{|c|}{ Final model } \\
\hline & $\begin{array}{c}\text { Skin } \\
\text { detachments } \\
\mathrm{n}(\%)\end{array}$ & $\begin{array}{c}\text { Adjusted OR } \\
\text { [Ci95\%] }\end{array}$ & Pvalue & $\begin{array}{c}\text { Adjusted OR } \\
\text { [Ci95\%] }\end{array}$ & Pvalue \\
\hline \multicolumn{6}{|l|}{ Average Age (years) } \\
\hline$<33.7$ & $13(43.3)$ & 1 & 0.4605 & & \\
\hline$\geq 33.7$ & $17(56.7)$ & $1.37[0.59-3.18]$ & & & \\
\hline \multicolumn{6}{|l|}{ Alcohol } \\
\hline Without Alcohol & $28(93.3)$ & $0.51[0.10-2.5]$ & 0.4090 & & \\
\hline With Alcohol & $2(6.7)$ & 1 & & & \\
\hline \multicolumn{6}{|l|}{ Seniority } \\
\hline $1-2$ years & $3(10)$ & 1 & & 1 & \\
\hline $2-3$ years & $3(10)$ & $2.64[0.46-15.08]$ & 0.2760 & $1.87[0.25-14.02]$ & 0.5409 \\
\hline 3 - 4years & $8(26.7)$ & $4.29[1.01-18.3]$ & 0.0489 & $6.2[1.21-31.6]$ & 0.0280 \\
\hline$>4$ years & $16(53.3)$ & $6.4[1.6-24.8]$ & 0.0067 & $8.22 \mid 1.93$ - 35.08] & 0.0044 \\
\hline \multicolumn{6}{|l|}{ Oil use } \\
\hline Shea butter & $20(66.7)$ & $1.67[0.45-6.14]$ & 0.4368 & $1.96[0.38-9.97]$ & \\
\hline Cotton & $4(13.3)$ & 1 & & 1 & 0.4128 \\
\hline castor & $6(20)$ & $2.87[0.86-9.52]$ & 0.0847 & $3.43[0.8-14.72]$ & 0.0966 \\
\hline \multicolumn{6}{|l|}{ Soap for cleaning } \\
\hline Without soap & $4(13.3)$ & 1 & & 1 & \\
\hline SN Citec & $19(63.3)$ & $1.6[0.41-6.3]$ & 0.4951 & $1.04[0.24-4.5]$ & 0.9532 \\
\hline Black soap & $7(23.4)$ & $4.8[1.38-16.2]$ & 0.0130 & $4.35[1.15-16.48]$ & 0.0303 \\
\hline \multicolumn{6}{|l|}{ Background } \\
\hline Without history & $7(23.3)$ & $3.3[0.78-14.2]$ & 0.1030 & $1.54[0.28-8.29]$ & 0.6153 \\
\hline Allergy & $5(16.7)$ & 1 & & & \\
\hline Dermatological & $18(60)$ & $1.5[0.56-4.9]$ & 0.4219 & $1.51[0.47-4.8]$ & 0.4832 \\
\hline
\end{tabular}

Table 5. Distribution of patients according to the type of psychosocial impact.

\begin{tabular}{ccc}
\hline Impact psycho-social & Number of situations & Percentage (\%) \\
\hline Anxiety & 10 & 8.9 \\
Contacts and wave avoidance & 44 & 39.3 \\
Indifferent & 32 & 28.6 \\
Resignation & 47 & 42.0 \\
Stigma & 80 & 71.4 \\
Conjugal life pertubation & 8 & 7.1 \\
\hline
\end{tabular}

are too basic such as soda, ash and too much acid (some residue from brewery) and corrosive products such as bleach that will aggravate the lesions instead of treating them [8] [9].

Concerning personal protective measures, the vast majority (99\%) justified the non-use of gloves by the fact they aggravated hands injuries. In fact, in contact with the machine blades, the gloves are perforated and the CNLS penetrates [9]. Contact dermatitis is common among workers in the cashew nut factory. This is why the current trend in other countries is the use of automatic shelling machine and adapted gloves to minimize contacts. 
The etiology of dermatitis is attributed to cashew nuts such as Eleonora, Anacardium is responsible for irritative and allergic dermatitis by chemical contact [6]. According to Cathérine PAQUET [10], her shell contains a highly irritating brown oily liquid. Dermatitis occurs during contact with this oily juice. The international literature reports this corrosive effect throughout the history of the chain [11] [12] [13] [14]. We observed mainly erythematous contact dermatitis (ECD). There are the most frequent of all occupational dermatitis [8] [9].

At the multivariate statistical analysis, the palmar keratoderma was significantly associated with those using castor oil $(\mathrm{p}=0.0020)$ and oil from cotton $(\mathrm{p}=$ 0.0081. Certain oils (cotton and castor) aggravate the situation without one knows why. Yet these oils have the reputation of relieving the burns [15]. The use of black soap and seniority age of more than 4 years was associated with skin detachments, highlighting the role of soda and repeated contacts with CNSL [9]. These lesions were localized on the hands which had a high relational, social and aesthetic value. Then the morbidity and aesthetic prejudice had a psychological impact on 109 employees ie $97.32 \%$. As for the psychosocial repercussions, the events were associated and often diversified. Women were stigmatized in $73.4 \%$ of cases (80/109). They avoided of contacts and greetings in $40.36 \%$ of cases (44/109). But in front of necessities and financial precariousness, they resigned themselves and ended by becoming indifferent. In spite of the understanding of the spouses in this struggle for survival, marital life was disrupted in $7.34 \%$ of cases (8/109).

We have not been able to find in the international literature a study on the psychological repercussions.

\section{Conclusion}

The prevalence of dermatitis in our study was $88.39 \%$ in many clinical presentations: Inflammatory erythematous lesions (86.4\%), associated with palmar keratoderma (70.9\%), skin detachment skin by chemical burns due to CNSL (30.0\%). The psychological impact of dermatitis was quite significant. The etiopathogenesis was clearly established on the data of the literature and the observations of the study. Associated factors have been identified. Cashew huskers had dermatitis with an impact on daily life. Then, working conditions and security of employment, hygiene attitudes and anacardic acid were identified as causes of this situation. It is imperious to take measures in collaboration with the occupational physicians to ensure these women's health at work and improve their quality of life. Indeed cashew industry is at full extension in Burkina Faso with the creation of new factories and recruitment of vulnerable women. Larger studies in many factories will undoubtedly identify the contours of the problem and propose suitable solutions to the benefit of cashew processing factories of Burkina Faso.

\section{References}

[1] Ministère de l'Emploi, du Travail et de la Jeunesse, CNSS, Direction de la 
prévention, de l'Action Sanitaire et Sociale (2007) Tableau des maladies professionnelles. [Table of Occupational Diseases]. 69 p.

[2] Frimat, P. and Fantoni-Quinton, S. (2001) Progrès en dermato-allergologie. [Progress in Dermato-Allergology]. Actes des Journées, Bruxelles. 261 p. https://books.google.bf/books/about/Progrès_en_dermato_allergologie.html

[3] Dezfoulian, B. (2011) Dermatoses Professionnelles. [Occupational Dermatosis]. Service de dermatologie CHU Sart Tilman. 60 p. http://www.stes-apes.med.ulg.ac.be.

[4] Ouedraogo, V., et al. (2009) Aspects médicolégaux des dermatoses professionnelles déclarées à la CNSS de 1979 à 2009. [Medicolegal Aspects of Occupational Dermatosis Reported to the CNSS from 1979 to 2009]. Rapport CNSS/OST.

[5] Ky-Diallo, K. (2016) Etat des lieux des impacts du CNSL sur les mains. [View of CNSL Impacts on Hands]. Rapport/ANASAM Burkina Faso.

[6] Gambillara, E., Spertini, F. and Leimgruber, A. (2010) Réactions cutanées allergiques et toxiques aux plantes. [Skin Allergic and Toxic Reactions to Plants]. Revue Médicale Suisse, 245, 824-829.

[7] Cisse, M., Mara, A., M.-M., Soumah, H., Baldé, A., Dabo, C., et al. (2012) Étude descriptive de la dermite de contact à la noix de cajou dans une usine de décorticage en Guinée. [Descriptive Study of Contact Dermatitis in a Cashew Nuts Shelling Factory in Guinea]. Annales de Dermatologie et de Vénéréologie, 139, B238.

[8] ILO (2004) Les maladies cutanées. [Skin Diseases]. Encyclopédie de sécurité et de santé au travail $3^{\text {ème }}$ édition française BIT 4000pp.

[9] Kgeraut, C. and Tripodi, D. (2001) Dermatoses-Toxicologie-Pathologie Professionnelle. [Dermatosis-Toxicology-Occupational Pathology]. Elsevier, Paris. Encyclopédie Médico-Chirurgicale 16-533-A10, Dermatologie, 98-795-A, 10, 27 p.

[10] Pecquet, C. (2007) Progrès en dermato-allergologie. [Progress in Dermato-Allergology]. Livre Paris Ed John Libbey, $148 \mathrm{p}$

[11] Mc Govern, T.W. and Barkley, T. (1998) Botanical Dermatology. International Journal of Dermatology, 37, 321-334.

[12] Guin, J.D. (2004) Occupational Contact Dermatitis to Plants. In: Kanerva, L., Elsner, P., Wahlberg, J., Maibach, H.I., Eds., Handbook of Occupational Dermatology, Springer, Berlin Heidelberg New York, 730-766.

[13] Marks, J.G., Fowler, J.F., Sheretz, E.F. and Rietschel, R.L. (1995) Prevention of Poison Ivy and Poison Oak Allergic Contact by Quaternium-18 Bentonite. Journal of the American Academy of Dermatology, 33, 212-216.

[14] Kurlan, Jg. and Lucky, A.W. (2001) Black Spot Poison Ivy. A Report of Five Cases and a Revue of Literature. Journal of the American Academy of Dermatology, 45, 246-249.

[15] Merabtine, E. (1998) Valorisation de la pomme de cajou: Différentes voies d'obtention de produits déshydratés pour une incorporation dans les produits laitiers, Mémoire de fin d'études d'ingénieur, École nationale supérieure des Industries alimentaires, Section Industries alimentaires régions chaudes (EnsiaSiarc), Montpellier, France, 2. [Valorization of cashew apple: Different ways of obtaining dehydrated products for incorporation into dairy-produces]. 
Submit or recommend next manuscript to SCIRP and we will provide best service for you:

Accepting pre-submission inquiries through Email, Facebook, LinkedIn, Twitter, etc. A wide selection of journals (inclusive of 9 subjects, more than 200 journals)

Providing 24-hour high-quality service

User-friendly online submission system

Fair and swift peer-review system

Efficient typesetting and proofreading procedure

Display of the result of downloads and visits, as well as the number of cited articles Maximum dissemination of your research work

Submit your manuscript at: http://papersubmission.scirp.org/

Or contact jcdsa@scirp.org 